\title{
Geo-Heritage Conservation: The Content Analysis Study of Kilim Geoforest Park, Langkawi
}

\author{
Noor Syarafina Mohd Fauzi ${ }^{1 *}$, Alamah Misni ${ }^{2}$, \\ Siti Mazwin Kamaruddin 2 , Puziah Ahmad 2 \\ ${ }^{1}$ Institute of Graduate Studies, Faculty of Architecture, Planning and Surveying, \\ Universiti Teknologi MARA,Shah Alam, Selangor, Malaysia. \\ 2Faculty of Architecture, Planning and Surveying, \\ Universiti Teknologi MARA, Puncak Alam, Selangor, Malaysia. \\ sya_finafauzi143@yahoo.com.my
}

\begin{abstract}
Geopark was a widely known concept for the global theme for promoting the tourism industry. It is protecting the world heritage and improving the local community's socioeconomic development. Currently, Geopark had faced a lot of risk and challenges of losing their identity and damages on historical assets due to an increasing demand for development. Therefore, Geopark area should be well managed and protected with strategic planning and approach. By using the content analysis technique, this research will determine the suitability and current sustainable conservation approach which suits the standard criteria and guidelines that have been set by UNESCO.
\end{abstract}

Keywords: Cultural heritage; Geo-heritage; Geopark; tourism.

eISSN 2398-4279 @ 2018. The Authors. Published for AMER ABRA cE-Bs by e-International Publishing House, Ltd., UK. This is an open access article under the CC BY-NC-ND license (http://creativecommons.org/licenses/bync-nd/4.0/). Peer-review under responsibility of AMER (Association of Malaysian Environment-Behaviour Researchers), ABRA (Association of Behavioural Researchers on Asians) and cE-Bs (Centre for EnvironmentBehaviour Studies), Faculty of Architecture, Planning \& Surveying, Universiti Teknologi MARA, Malaysia.

DOI: https://doi.org/10.21834/ajqol.v3i12.145 


\subsection{Introduction}

Heritage includes both tangible and intangible elements which include nature, culture, monument, archaeological sites, geological element and others. Historical elements could identify the level of identity and have a high value in becoming the proof towards human history and its surrounding environment (Fauzi \& Misni, 2016). Each of the historical elements has a specific value towards the surrounding environment or the local community itself. According to Eder (2004) more and more countries have started to develop schemes for recognizing important geological and geomorphological sites within their national boundaries.

In Malaysia, the tourism sector has contributed significantly to the Gross Domestic Product (GDP). For example, in 1988 this sector contributed approximately RM9.8 billion and it increased to RM31. 1 billion in the year 2000 thus this also resulted in the increasing number of tourist arrival in 2010 (Samat \& Harun, 2013). The increasing demands towards modern development on the tourism industry, facilities and tourism activities has given a big impact towards the historical site and its elements (Fauzi \& Misni, 2016). Tourism development often results in the use of natural resources that are less sustainable, and gives the potential and negative impact on the environment (Sun, 1998).

A geopark is defined as a territory with a particular geological heritage of international significance, rarity or aesthetic appeal, which is developed as part of an integrated concept of conservation, education and local economic development (UNESCO, 2016). According to Azman et al. (2010), a Geopark is divided into three main components which are protection and conservation; tourism-related infrastructural development; and socio-economic development and the key success factors for Geopark concept towards sustaining the heritage value. The focus of the study is to analyse current management planning and identify the management and conservation aspect involve in developing a Geopark.

\subsection{Area of Study}

Langkawi Geopark consists of three areas known as Machinchang Cambrian Geoforest Park, Kilim Karst Geoforest Park and Dayang Bunting Marble Geoforest Park. The Langkawi Geopark has recorded as made up of 99 tropical islands off the northwestern coast of Peninsular Malaysia covering an area of about 478 square kilometers (Leman et al., 2008) which rich in magnificent landscape beauty and various historical elements.

Langkawi Geopark has been gazetted as Geopark by United Nation of Educational, Scientific and Cultural Organisation (UNESCO) on June 1, 2007 and became the 52nd member of the International Network of Geoparks (GGN) (LADA, 2014). However, this paper will cover the area of Kilim Karst Geoforest Park (KKGP) as the area has recorded a various number of historical and natural assets in both geological and biological elements rather than the other two areas of Langkawi Geopark. KKGP consist of lots of sensitive areas such as mangrove area, karst, caves and others. Based on the tourism activities, the KKGP area has been exposed to a major disturbance and faced a lot of risks towards the surrounding environment.. 


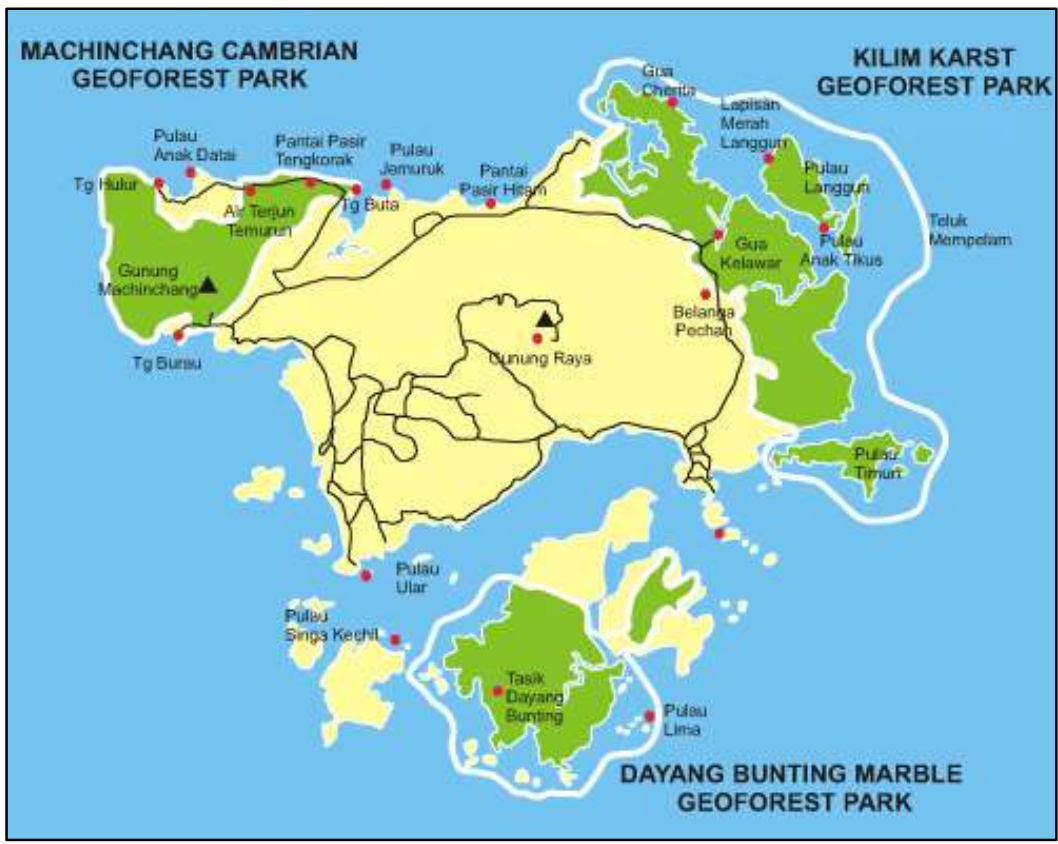

Figure 1: The location plan of Kilim Karst Geoforest Park Langkawi (Source: Google, 2016)

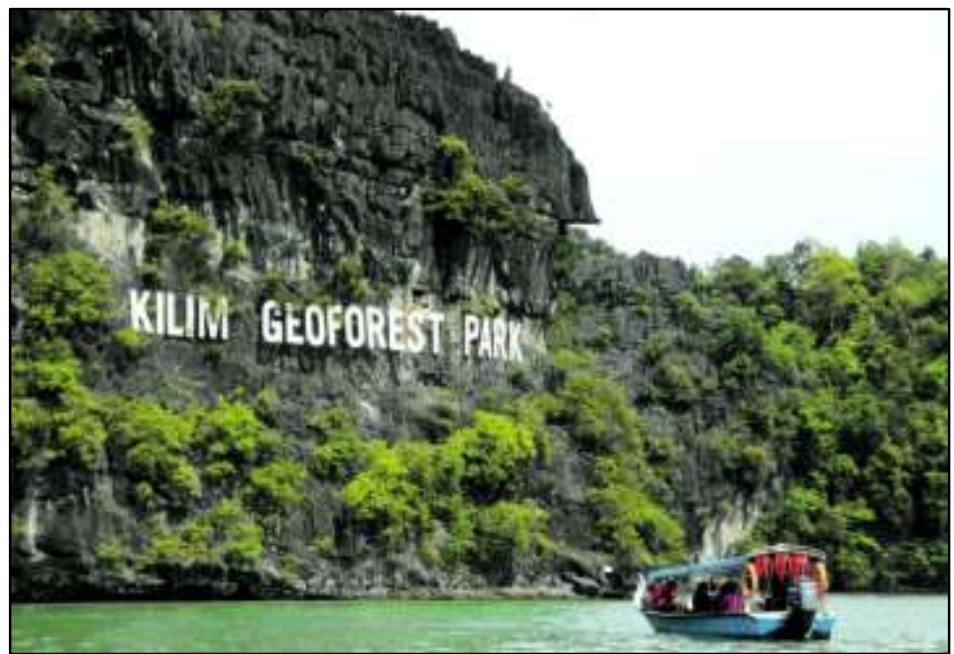

Figure. 2: The famous karst landscape at Kilim Karst Geoforest Park, Langkawi (Source: Google, 2016) 


\subsection{The Content Analysis Study}

As a naturally rich and sensitive area, KKGP is exposed towards various risks and problems, especially regarding the rapid development growth and also ecotourism demand. Each year, there is an emerging issue that becomes a major concern such as the destruction of mangrove area (Augustin, 2016) and also the pollution problems that resulted from tourism activities (Idris, 2016). According to UGA (2012), the content analysis technique is referred and usually used to make replicable and valid inferences by interpreting the textual material. Thus, this technique will systematically evaluate the data recorded in text such as documents, oral communication, or graphics which related to Langkawi Geopark and KKGP.

\subsection{Document analysis 1: UNESCO criteria and guideline for Geopark}

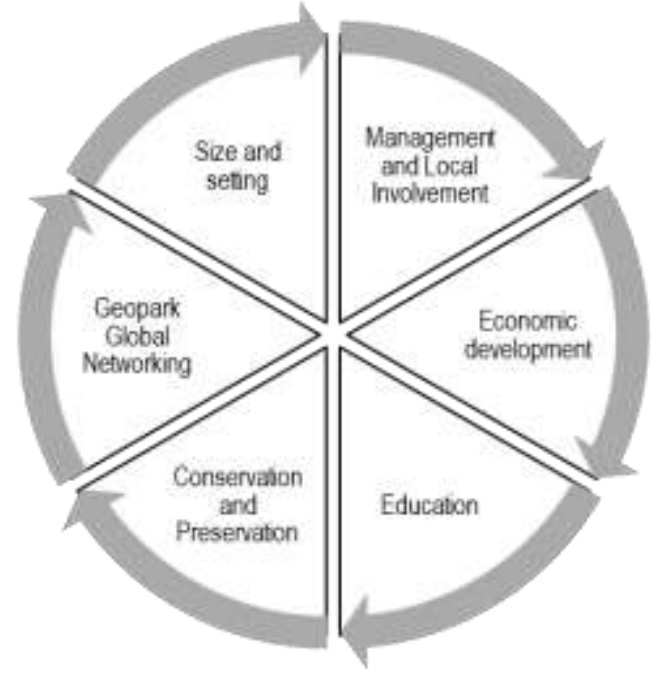

Figure 3: Six main criteria for site-seeking Geopark status by UNESCO (Source: Modified from GGN (2006))

According to UNESCO (2016), the Geopark idea was a management concept which focuses on the protection, education and sustainable development that bottom-up approach of combining conservation with sustainable development while involving local communities.

UNESCO Global Geopark Network (GGN) has prepared some basic criteria and guidelines in order to help the other country which applied for the Geopark status. The criteria and guidelines that have been set up have provided a basic standard and structure that should be taken into consideration of all sites- seeking Geopark status. As stated in GGN (2010), Geopark member should have the same approach and objectives such as:

i. To protect and preserve their historical elements for present and future generations

ii. To educate and increase awareness of the public towards the earth science and natural environment matters. 
iii. To maintain the sustainable development practices.

iv. To ensure the participatory schemes and co-partnership in order to foster heritage conservation and management aspect.

v. To improve and stimulate the research and education towards historical elements and nature.

vi. To contribute actively and join the collaboration in developing initiatives and activities through communication, publication, workshop and others.

vii. To contribute towards any kind of publication that related to Geopark practices and approach

Thus, by according to the criteria, guideline and objectives by the GGN, all of the Geopark members should already have a clear vision and perspectives towards developing and protecting their own Geopark area.

\subsection{Document analysis 2: Document prepared by the Langkawi Development Authority (LADA)}

Kilim Karst Geoforest Park possesses a richness in Geo-diversity including karst landscape, rock formation, fossils, and natural beauty such as flora and fauna. These elements are considered as the historical and priceless assets of KKGP. Langkawi Development Authority (LADA) has been appointed as a coordinator of Langkawi Geopark by the Government of Kedah in May 2006. Meanwhile, in 2007, Ministry of Finance has given a funding as for LADA to develop planning for the Geopark project (LADA, 2016). Thus, the role of LADA is to prepared a proper management planning and evaluation assessment for the Langkawi Geopark.

According to LADA (2016), in order to implement the policies ad guidelines towards the Langkawi Geopark area, there is four committees that have been formed by LADA which is technical committee, development committee, marketing committee, and conservation committee. Besides, there is also the contribution from various ministry and government agencies which created a membership towards the development of Langkawi Geopark. LADA is fully responsible towards the development and management planning of the Geopark area.

Therefore, on January 1, 2011, LADA has been collaborating with Universiti Kebangsaan Malaysia (UKM) to provide an action plan known as the Final Draft of Langkawi Geopark Action Plan. In preparing the action plan, the research team has made a discussion and a few interviews with related groups and individuals. There are also five discussion workshop sessions that have been held to complete this action plan (LADA \& Kumpulan Governans Pemuliharaan Warisan \& Pendidikan Universiti Kebangsaan Malaysia (UKM), 2012). In addition, Initial Report, Technical Report, Interim Report and also Historical Langkawi Report have been referred by the research team from LADA and UKM.

By referring to the GGN criteria and guidelines, LADA also has prepared and identified the main component aspect of managing the Langkawi Geopark (Figure 4). The component aspect is the guidelines in preparing a systematic and functional framework for the Geopark. 


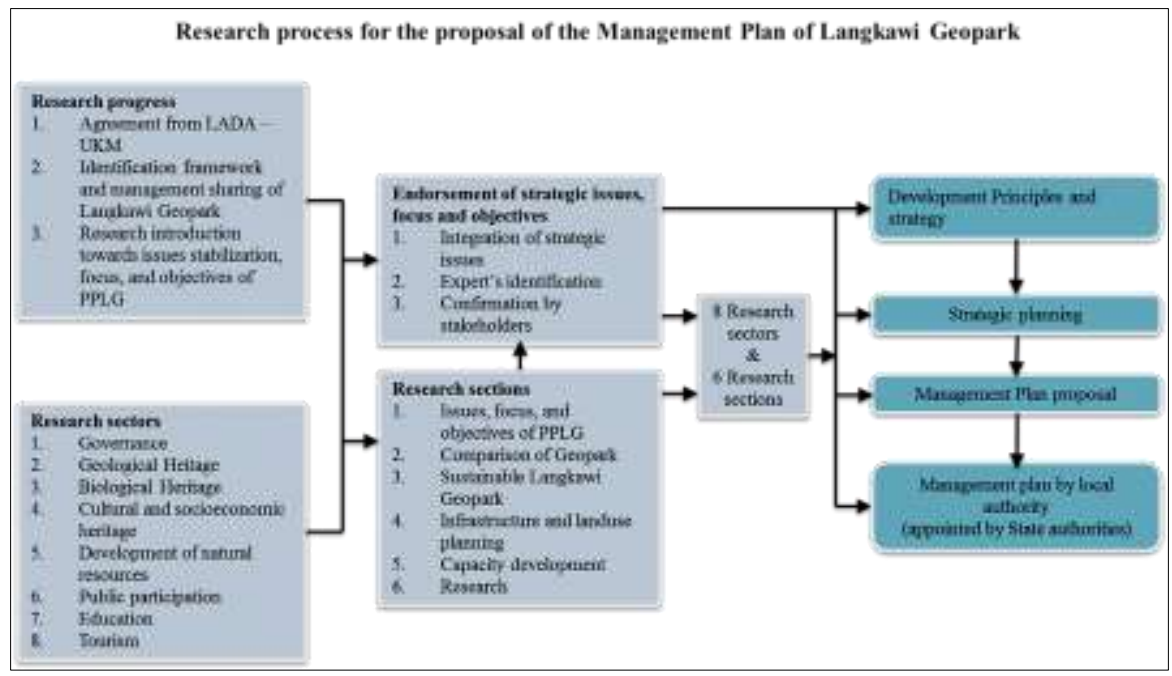

Figure 4: Research process flow in preparing the Final Draft of Langkawi Geopark Action Plan (Source: Modified from LADA and Kumpulan Governans Pemuliharaan Warisan \& Pendidikan Universiti Kebangsaan Malaysia (UKM) (2012))

Table 1. Group of person involved in the workshop while preparing the Final Draft of Langkawi Geopark Management Plan: Action Plan

\begin{tabular}{llc}
\hline Category & Group background & Numbers of person \\
\hline 1. & Government agency & 103 \\
2. & Private Bodies & 26 \\
3. & Non - government & 10 \\
4. & Local community & 54 \\
5. & School teacher & 15 \\
6. & Student & 18 \\
\hline Total & & 226 \\
\hline
\end{tabular}

Table 2. The component aspect in managing Langkawi Geopark

\begin{tabular}{cl}
\hline No. & Component aspect in managing Langkawi Geopark \\
\hline 1. & Governance \\
2. & Conservation of Geological heritage \\
3. & Conservation of Biological heritage \\
4. & Conservation of Cultural heritage \\
5. & Resource and Environmental Management \\
6. & Tourism \\
7. & Public education \\
8. & Local community involvement \\
9. & Land use Planning and Physical Development \\
10. & Global Network \\
\hline
\end{tabular}

(Source: Modified from LADA and Kumpulan Governans Pemuliharaan Warisan \& Pendidikan Universiti Kebangsaan Malaysia (UKM) (2012)) 


\subsection{Document analysis 3: Document prepared by National Hydraulic Research Institute of Malaysia (NAHRIM) and Ministry of Natural Resources and Environment Malaysia (NRE).}

On March 2015, NAHRIM and NRE has prepared a final draft report; The Study on Riverbank Erosion Due to Shipwake at Kilim Geoforest Park, Langkawi. NAHRIM and NRE (2015) stressed, since the establishment of the Geopark, a few areas and elements around the Geopark faced a problem and get worsened each year. The tourism demands that increased rapidly over the years had affected the area of KKGP and had given the negative impacts towards the whole Geopark surrounding as follows:
i. Erosion
ii. Pollution
iii. Disruption of the mangrove reserved area and the overall landscape of Kilim Geopark
iv. Disturbance towards the existing Geopark's ecosystem

The uncontrolled number of visitors at KKGP has resulted in an increased in boat trips and boat number cruising around the Geopark. Thus, the negative impacts such as the propagating waves from the boat had led to the erosion of the riverbank, damaging the mangrove tree and erosion of the karst.

As a tourism destination, the operation boats were the main attraction around Kilim Karst Geoforest Park. Tourist needs to use a boat in order to enjoy the tour around the area. According to NAHRIM and NRE (2015), a total number of boat trips passing through Kilim Jetty on 2014 was recorded as 27,732 in an average of 2300 boat trips a month. However, every single type of ships, high-speed crafts (HSC) or boats will generate waves and contributes to the erosion problems around Kilim. In addition, here are the points observed from the further research by NAHRIM:

i. Ship Generated Waves (SGW) was the main contributor to the erosion. A boat with higher speed will usually generate waves with large wave height, which contain a large amount of destructive energy to the river bank, destruction of fragile water plants, disturbance of silt and others.

ii. Waves hitting the river banks also affect the growth of mangrove because the facts are that mangrove grows best in a depositional environment with low wave energy.

iii. Boat size (Length), speed and loading are the three most critical contributors to SGW.

Thus, based on the literature studies done by NAHRIM, the result has recommended that approximately a speed of 6 knots (or less) for the similar inland waterway area was an acceptable speed for the inland waterways boat. This acceptable speed of boats will produce SGW with a small height, which significantly will reduce the erosion rate at the riverbank. Currently, the 27 feet boats were the most commonly operating boats used along the Kilim river. Plus, according to NAHRIM's previous study, mangrove can survive well in the area that having current speed waves of less than $0.3 \mathrm{~m} / \mathrm{s}$ but a few areas along the Kilim river could have the maximum current speed up to $0.4 \mathrm{~m} / \mathrm{s}$. 


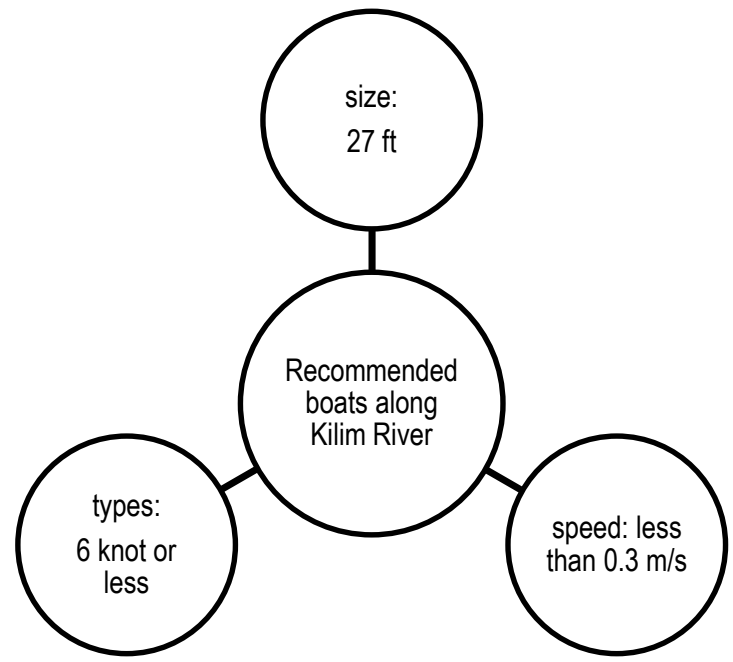

Figure 5: The recommended criteria of operating boats that should be used along the Kilim River.

(Source: Modified from NAHRIM and NRE (2015))

\subsection{Results and Discussion}

As from the global level, the GGN had formed a useful idea towards developing a worldwide membership in order to exchange ideas and information. The active membership program could inspire the Global Geopark member to continuously improve and sustaining their Geopark area. The criteria and guidelines prepared have become the basic standard towards all the Geopark around the world. By referring to the standards, Geopark member could basically develop a management planning structure by following the criteria and guidelines. Thus, it is much easier for the GGN to manage and conducting an assessment towards all of the Geopark members.

Besides, as for the country level, LADA has struggled with developing Langkawi Geopark. By referring to the analysis, LADA has successfully attracted local community involvement in preparing the Geopark development idea. In addition, LADA also widely referred to the basic Geopark criteria towards their management structure. As a result, the component aspect of managing the Langkawi Geopark has fulfilled each criteria set by UNESCO Global Geopark. Nevertheless, there are many more elements and detail guidelines that should be focused and prepared by LADA. Currently, the action plan lacks in the specific guidelines for managing the overall area of Langkawi Geopark.

Meanwhile, it was glad to have a specific research done such as NAHRIM at the KKGP area. KKGP consist of various kinds of historical elements such as geological and biological elements and others. Thus, it is important to have certain guidelines for each of the elements. Specific guideline towards the boat tour activities and a number of tourist visit per day should be provided and well-monitored. It was an urgent call for restructured the current activities and development planning before the problem at KKGP has become worse and lastly 
resulted in the loss of the historical and natural elements around KKGP. Plus, KKGP has a proper basic structure and implementation towards conservation and management planning. The UNESCO Global Geopark has lead LADA to have a stable component of Geopark, while LADA has prepared an effort towards managing and providing a sustainable approach for all Langkawi Geopark area. Meanwhile, an appointed government body such as NAHRIM had covered the specific research towards KKGP area. Thus, supposedly KKGP could have been provided with specific guidelines and proper conservation plan in order to sustain the originality and sustainability of the historical elements and value. By using all of the sources of global, country and specific area level information, KKGP should have the suitable conservation plan in order to specifically and systematically protects the area.

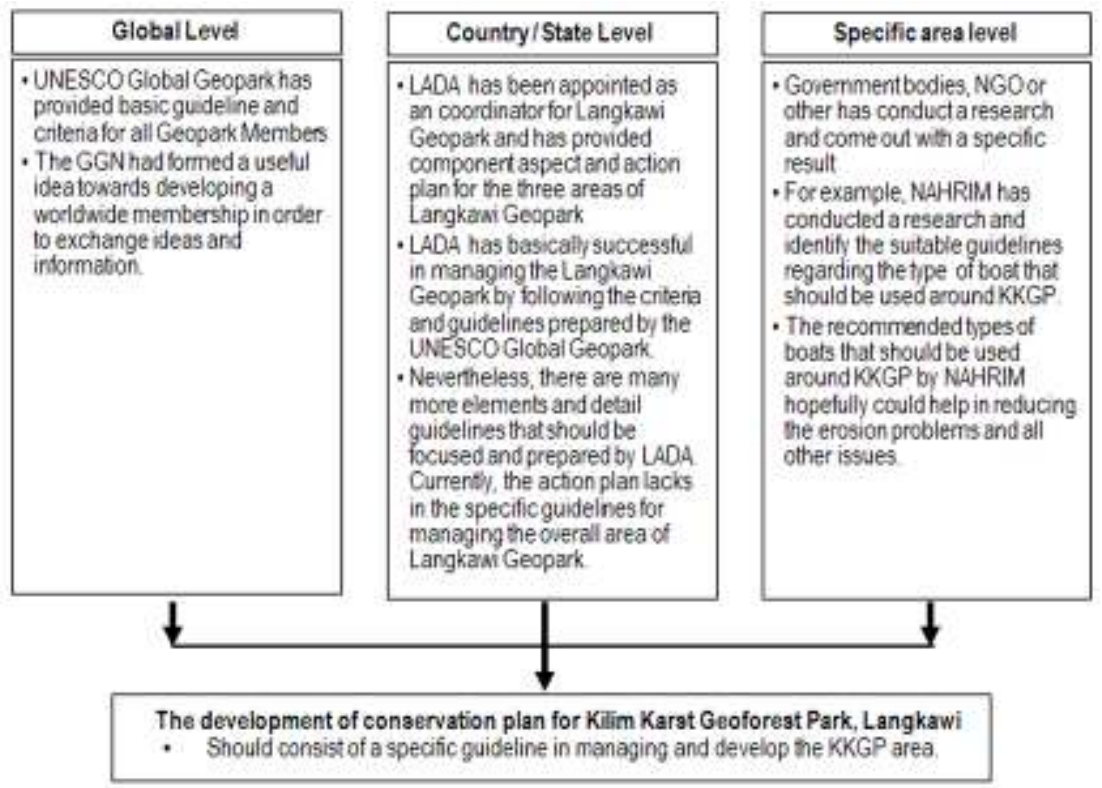

Figure 6: The flow of management level in providing the suitable measures and conservation for KKGP

\subsection{Conclusion}

LADA had taken full responsibilities towards its role in prepared a few initiatives to deal with the management and conservation of Langkawi Geopark. However, further effort needs to be directly applied to overcome the problems as it is becoming worse. Damages and loss of geological and historical assets could affect the development of Langkawi Geopark. The conservation plan is needed and should be more specific and wisely planned as for the sake of each element. It has to be conserved in a different and particular ways. Furthermore, Geoheritage elements and the sustainable development of the Langkawi Geopark especially in 
KKGP area should be improved and well - practiced in order to sustain our precious historical value.

\section{Acknowledgement}

This research was supported in part by LESTARI Grant, Universiti Teknologi MARA (600IRMI/DANA 5/3/LESTARI (0148/2016)).

\section{References}

Augustin, R. (2016). Precious mangroves in Langkawi Geopark illegally destroyed. Retrieved from http://www.freemalaysiatoday.com/category/nation/2016/01/20/precious-mangroves-in-langkawi-geopark-illegallydestroyed/

Azman, N., Halim, S. A., Liu, O. P., Saidin, S., \& Komoo, I. (2010). Public education in heritage conservation for geopark community. Procedia-Social and Behavioral Sciences, 7, 504-511.

Eder, F. W., Margarete Patzak. (2004). Geoparks - geological attractions: A tool for public education, recreation and sustainable economic development.

Fauzi, N. S. M., \& Misni, A. (2016). Geoheritage Conservation: Indicators Affecting the Condition and Sustainability of Geopark-A Conceptual Review. Procedia-Social and Behavioral Sciences, 222, 676-684.

GGN. (2006). Guidelines and Criteria for National Geopark seeking UNESCO's assistance to join the Global Geopark Network. UNESCO, Division of Ecological and Earth Sciences, 115 - 118.

GGN. (2010). Guideline and Criteria for Canadian sites seeking Geopark designation within the Global Geopark Network (GGN). Canadian Federation of Earth Science.

Idris, S. M. M. (2016). Mangrove forest in Kilim Geo Park under threat. Mangroves here are being threatened by tourist boat activities and pollution due to littering. Retrieved from http://www.freemalaysiatoday.com/category/opinion/2016/05/27/mangrove-forest-in-kilim-geo-park-under-threat/

LADA. (2014). Geopark. Retrieved from http://www.lada.gov.my/v2/en/product/geopark.html

LADA. (2016). Langkawi UNESCO Global Geopark. Retrieved from https://www.lada.gov.my/index.php/mengenaikami/produk/langkawi-unesco-global-geopark

LADA, \& Kumpulan Governans Pemuliharaan Warisan \& Pendidikan Universiti Kebangsaan Malaysia (UKM). (2012). Pelan Pengurusan Langkawi Geopark 2012 - 2030: Pelan Tindakan. Malaysia: Institut Alam Sekitar dan Pembangunan (LESTARI).

Leman, M. S., Komoo, I., Mohamed, K. R., Ali, C. A., Unjah, T., Othman, K., \& Yasin, M. H. M. (2008). Geology and Geoheritage Conservation Within Langkawi Geopark, Malaysia. Retrieved September, 6, 2013.

NAHRIM, \& NRE. (2015). The Study on Riverbank Erosion Due to Shipwake at Kilim Geoforest Park, Langkawi. Malaysia: NAHRIM.

Samat, N., \& Harun, N. (2013). Urban development pressure: Challenges in ensuring sustainable tourism development in Langkawi Island. Procedia-Social and Behavioral Sciences, 91, 385-394. 
Sun, D. W., D. . (1998). Review of Studies on Environmental Impacts of Recreation and Tourism in Australia. Environmental Management, 323 - 338.

UGA. (2012). What is content analysis? Retrieved from https://www.terry.uga.edu/management/contentanalysis/research/

UNESCO. (2016). UNESCO Global Geoparks. Earth Science. Retrieved from http://www.unesco.org/new/en/natural-sciences/environment/earth-sciences/unesco-global-geoparks/ 